Final version:

Maon, F., Lindgreen, A., and Vanhamme, J. (2009), "Developing supply chains in disaster relief operations through cross-sector socially oriented collaborations: a theoretical model", Supply Chain Management: An International Journal, Vol. 14, No. 2, pp. 149-164. (ISSN 1359-8546)

For full article, please contact LindgreenA@cardiff.ac.uk

\title{
Developing Supply Chains in Disaster Relief Operations through Cross-sector Socially Oriented Collaborations: A Theoretical Model
}

François Maon, ${ }^{1}$ Université catholique de Louvain

Adam Lindgreen, ${ }^{2}$ Hull University Business School

Joëlle Vanhamme, ${ }^{3}$ Erasmus University Rotterdam

\footnotetext{
${ }^{1}$ François Maon, Department of Marketing, Louvain School of Management, Université catholique de Louvain, Place des Doyens 1, 1348 Louvain-la-Neuve, Belgium. E-mail: francois.maon@uclouvain.be. Telephone: + 32 10478457.

${ }^{2}$ For all correspondence: Professor Adam Lindgreen, Department of Marketing and Business Strategy, Hull University Business School, Hull HU6 7RX, the United Kingdom. E-mail: a.lindgreen@ hull.ac.uk. Telephone: + 441482463096.

${ }^{3}$ Dr. Joëlle Vanhamme, Department of Marketing, RSM Erasmus University, P.O. Box 1738, 3000 DR Rotterdam, the Netherlands. E-mail: jvanhamme@rsm.nl. Telephone + 31104081194.
} 


\section{BIOGRAPHICAL SKETCHES}

François Maon currently is undertaking Ph.D. studies at Université catholique de Louvain, examining strategies for implementation and stakeholder dialogue development. François has conducted research in Belgium, France, and the Netherlands. He has presented several papers at international marketing and business society conferences in Europe and the United States and has articles forthcoming in Academy of Management: Best Papers Proceedings 2008 and Journal of Business Ethics.

Dr. Adam Lindgreen is Professor of Strategic Marketing at Hull University Business School. Adam received his Ph.D. from Cranfield University. He has published in several journals, including British Food Journal, Business Horizons, Industrial Marketing Management, Journal of Advertising, Journal of Business Ethics, Journal of Business and Industrial Marketing, Journal of Marketing Management, Journal of Product and Innovation Management, Journal of the Academy of Marketing Science, and Psychology \& Marketing, among others. His research interests include business and industrial marketing, consumer behavior, experiential marketing, relationship and value management, and corporate social responsibility. He serves on the board of many journals.

Dr. Joëlle Vanhamme is Assistant Professor of Marketing at RSM Erasmus University. Joëlle received her Ph.D. from Université catholique de Louvain. She has published in Business Horizons, Industrial Marketing Management, Journal of Economic Psychology, Journal of Retailing, Psychology \& Marketing, and Recherche et Applications en Marketing, among others. Her research interests include the influence of emotions on marketing variables, including customer satisfaction, ambient advertising, corporate social responsibility, gift 
giving, word-of-mouth marketing, and senior marketing. She serves on the board of Industrial Marketing Management and Recherche et Applications en Marketing. 


\title{
Developing Supply Chains in Disaster Relief Operations through Cross-sector Socially Oriented Collaborations: A Theoretical Model
}

\begin{abstract}
Purpose - This study provides insights into corporate achievements in supply chain management (SCM) and logistics management and details how they might help disaster agencies. The authors highlight and identify current practices, particularities, and challenges in disaster relief supply chains.
\end{abstract}

Design/methodology/approach - Both SCM and logistics management literature and examples drawn from real-life cases inform the development of the theoretical model.

Findings - The theoretical, dual-cycle model that focuses on the key missions of disaster relief agencies: first, prevention and planning and, second, response and recovery. Three major contributions are offered: (1) a concise representation of current practices and particularities of disaster relief supply chains compared with commercial SCM; (2) challenges and barriers to the development of more efficient SCM practices, classified into learning, strategizing, and coordinating and measurement issues; and (3) a simple, functional model for understanding how collaborations between corporations and disaster relief agencies might help relief agencies meet SCM challenges.

Research limitations/implications - The study does not address culture clash-related considerations. Rather than representing the entire scope of real-life situations and practices, the analysis relies on key assumptions to help conceptualize collaborative paths. 
Practical implications - The study provides specific insights into how corporations might help improve the SCM practices by disaster relief agencies that continue to function without SCM professional expertise, tools, or staff.

Originality/value - Sharing supply chain and logistics expertise, technology, and infrastructure with relief agencies could be a way for corporations to demonstrate their good corporate citizenship. Collaborations between corporations and disaster agencies offer significant potential benefits.

Paper type - Research article.

Keywords - supply chain; disaster relief operations; corporate social responsibility 


\title{
Developing Supply Chains in Disaster Relief Operations through Cross-sector Socially Oriented Collaborations: A Theoretical Model
}

\author{
"To think strategically about cross-sector collaborations, \\ you must have a framework that enables you to envision strategic options." \\ —James E. Austin
}

\section{INTRODUCTION}

The term "disaster" usually is reserved for "a serious disruption of the functioning of society, causing widespread human, material or environmental losses which exceed the ability of the affected people to cope using only its own resources" (United Nations, 1992: 21). Furthermore, existing literature classifies four types of disasters (Van Wassenhove, 2006): natural, sudden onsets (e.g., earthquakes, hurricanes, tornadoes); human-made, sudden onsets (e.g., terrorist attacks, coup d'états, industrial accidents); natural, slow onsets (e.g., famines, droughts, poverty); and human-made, slow onsets (e.g., political and refugee crises). In this context, relief refers to "the emergency food, shelter and services provided in the immediate aftermath of a natural or man-made disaster" (Thomas, 2003b: 4) and often entails a foreign intervention into a society with the aim of helping local people (Long and Wood, 1995). Therefore, the basic goal of disaster relief agencies is to minimize the impact of disasters and reduce the suffering of affected people (Kelly, 1995).

During the past two decades, the number of natural disasters, including floods, cyclones, and droughts, has quadrupled (Oxfam, 2007); as a result, disaster relief operations now rank high on political agendas (Kovács and Spens, 2007). Worldwide, an average of 400-500 natural 
disasters strike per year, up from a yearly average of 125 in the early 1980 s. The number of people affected by such disasters has risen from some 174 million to more than 250 million per year (United Nations, 2007). Various reasons may explain the growth of disaster events, including increased urban concentrations and environmental degradation (BBC, 2004). Human-made disasters add to the totals with incidents caused by political instability, such as terrorism, war, and ethnic cleansing, or social factors, including racism, exclusion, and religious persecution (Oliver-Smith, 2006). Social factors in turn often create political instability, which may lead to conflicts due to the displacement of people (Kolmannskog, 2008; Oliver-Smith, 2006). A clear relationship also emerges between a given geographical location's vulnerability to disasters and its level of social, economic, and technological development. For example, between 1990 and 1998, approximately 94 percent of major natural disasters and more than 97 percent of all natural disaster-related deaths occurred in developing countries (World Bank, 2001). Predictions suggest the number of natural and human-made disasters will increase five-fold in the next 50 years (Thomas and Kopczak, 2005); hence, the need for efficient disaster relief operations is clear (McEntire, 1999).

In 2004, the budget of the top-10 aid agencies exceeded US\$14 billion (Thomas and Kopczak, 2005); their operations and logistics often entail complex management activities deployed in special circumstances. Recent experiences_-for example, the tsunami in the Indian Ocean in 2004 or hurricane Katrina in 2005 - contribute to a greater understanding of the enormous complexities and numerous difficulties that relief operations agencies face (Garner and Harrison, 2006; Thomas and Fritz, 2006; Thomas and Kopczak, 2007). In this context, SCM and logistics may be crucial to ensure the success of relief operations (Chomilier, Samii, and Van Wassenhove; 2003; Gustavsson, 2003; Thomas and Kopczak, 2007), because approximately 80 percent of all relief operations interact with supply chains at some point 
during their efforts (Fritz Institute, 2007). Yet few disaster relief agencies pay attention to the design and implementation of supply chain or logistics management operations; fewer still recognize that such operations have a key strategic function (Thomas, 2003a, 2005). Rather, most resources go to support the more visible aspects of disaster relief operations, meaning that agencies typically lack staff who possess supply chain and logistics management competencies and, in turn, that their operations may not be as effective and efficient as possible.

Our study contributes in two major areas. First, although differences between commercial and disaster relief supply chains certainly exist, the skills and competencies required to excel in commercial supply chain and logistics management generally are the same skills and competencies that are needed to carry out disaster relief operations (University of Arkansas, 2005). Cross-learning opportunities therefore could provide agencies with significant insights into how corporations master the process of planning, implementing, and controlling their supply chain operations (Thomas and Kopczak, 2007; Van Wassenhove, 2006). The expertise, technology, and infrastructure employed in the commercial sector, for example, could contribute to the development of more effective and efficient supply chain and logistics relief operations (Thomas, 2004; Trunick, 2005). Using supply chain and logistics management literature and examples drawn from real-life cases, we contribute to literature by providing various insights into modern corporate achievements in supply chain and logistics management and then detailing how they might help disaster relief agencies improve their efforts. In particular, we highlight and identify current practices in disaster and relief supply chains; some particularities of such supply chains; challenges, or even barriers, to developing more effective and efficient relief supply chains; and the potential benefits of collaboration between corporations and disaster relief agencies. 
Second, at a time when corporations experience growing pressure to demonstrate their corporate social responsibility (CSR) and can no longer be concerned solely with increasing profits (Carroll, 1979; Lichtenstein, Drumwright, and Braig, 2004; Lindgreen, Swaen, and Johnston, 2008; Luo and Bhattacharya, 2006; Maignan, Ferrell, and Hult, 1999), sharing supply chain and logistics expertise, technology, and infrastructure with relief agencies could be a way to demonstrate their good corporate citizenship. For example, the international shipping companies TNT and DHL (Gupta and Perepu, 2008; Samii and Van Wassenhove, 2004; Spring, 2006), as well as Corporations for Humanity (Thomas and Fritz, 2006), are developing structured partnerships with disaster relief agencies. In this context, we further contribute to existing literature by theoretically establishing a functional model for understanding how support from corporations and collaborations between corporate actors and disaster relief agencies might help the latter ones meet SCM challenges; this model consists of three strategic perspectives on cross-sector collaborations: financial, capability, and entanglement perspectives. Together, these elements suggest options for collaborative actions and programs that might improve SCM practices from a CSR point of view.

To this end, we structure the remainder of this article as follows: First, we briefly review relevant literature to establish a conceptual and contextual background. Second, we discuss our research objectives and the methodology we use to meet them. Third, we present our findings and propose a theoretical model for understanding the role of corporations in disaster and relief supply chains. Fourth and finally, we discuss the contributions of our model, as well as its limitations, and avenues for further research.

\section{MODELS}




\section{Existing Models: Linear Sequence Models versus Cyclical Models}

The logistics that disaster relief operations must consider include planning, procurement, transport, warehousing, tracking, and tracing. As emphasized by Kelly (1998), the simplest disaster relief model depicts a linear sequence of pre-event, disaster, and post-event. Building on this, the National Governors Association's (1979) now widely accepted conceptualization suggests a four-stage standard process model of disaster relief that includes preparedness, response, recovery, and mitigation. In a similar way, Ludema and Roos (2000, cited in Tatham and Kovács, 2007) characterize disaster relief operations as consisting of emergency, elementary (or subsistence), rehabilitation, and development relief; preparation may be an additional phase (Kovács and Spens, 2007). Regardless of their included elements though, linear conceptualizations of disaster relief remain subject to criticisms (cf. Kelly, 1998), prompting the conceptualization of more cyclical models (e.g., Anderson, 1985; Carter, 1991; Cuny, 1985; Safran, 2003).

\section{A Theoretical Model of Disaster Relief: Dual-Cycle Model}

Our theoretical model we discuss next is based on a dual-cycle model of disaster relief operations. On the one hand, the model features the operational actions of disaster reaction and recovery, including an emergency response stage followed by a rehabilitation and reconstruction stage. On the other hand, we ensure the inclusion of strategic actions for disaster prevention and anticipation, such as the mitigation and preparedness stages. Figure 1 summarizes our proposed model.

Insert Figure 1 about here 
Within each distinct cycle, the model reveals that stages are not mutually exclusive; rather, overlaps are common. Different stages_and activities within these stages—may even occur at the same time for different population segments, and some relief operations are relevant to more than one stage (Haas, Kates, and Bowden, 1977; Neal, 1997). The stages are not independent entities with one stopping and the next following (Hogg, 1980; Shaluf, 2008); the fact that the stages are interrelated enables them to operate concurrently. For example, mitigation and reconstruction efforts are often simultaneous and ideally should be developed in parallel, though not necessarily by the same actors. Similarly, interconnected preparedness and emergency response stages may be partly concurrent, because supply chains must be built quickly. In practice, some disaster relief agencies focus almost entirely on emergency relief operations and their tactical planning, whereas others enlarge their scope of their operations or focus on longer-term operations related to rehabilitating the disaster area. These latter agencies also work to minimize or avoid future disasters by strategically applying their accumulated experience and knowledge.

By emphasizing the specific missions of the disaster relief agencies, this model offers an innovative, constructive representation of disaster relief operations that underlines the dualcyclical nature of these operations. Moreover, the model provides a simple framework for developing a more thorough understanding of SCM practices in disaster relief operations. Before discussing the model, we consider how cross-sector (between corporations and relief agencies), socially oriented collaborations are appearing in the disaster relief sector; such collaborations allow best practices in SCM be transferred from corporations to relief agencies.

\section{CORPORATE SOCIAL RESPONSIBILITY}


During the past two decades, CSR has achieved business prominence, largely as a result of activities by pressure groups, as well as the emergence of the "market for virtues," which includes socially responsible investments and creates pressures to adopt CSR initiatives (Brammer and Millington, 2003; Lindgreen, Swaen, and Johnston, 2008; Vogel, 1978, 2005). Many organizations support or develop their own CSR programs (e.g., Gupta and Chary, 2006; Rajshekar and Iyengar, 2004), implement ethical codes of conducts and charters (Campbell, 2006; Kolk and Van Tulder, 2002), collaborate with nongovernmental organizations (NGOs) (Nijhof, de Bruijn, and Honders, 2008; Powell-Smith, 2005) and international federations (Wills, 2002) or within CSR networks (e.g., Business for Social Responsibility; CSR Europe), or attempt to reconsider value and ethical issues associated with their business model and organizational culture (Joyner and Payne, 2002).

As a multifaceted concept, CSR definitions are numerous and varied (Garriga and Melé, 2004; Maon, Lindgreen, and Swaen, 2008). However, for the purposes of this study, we accept the definition proposed by Kotler and Lee (2005: 3), who regard CSR as an organization's commitment to improve community well-being by way of discretionary business practices and contributions of the organization's resources. The World Business Council for Sustainable Development further emphasizes that through CSR, organizations can contribute to sustainable economic development by working together not only with their employees and families but also the local community, and society at large, to improve their quality of life (Holme and Watts, 2000). From a CSR perspective, organizations may be instrumental in the construction of a better world (Friedman and Miles, 2002).

Cross-sector, socially oriented collaborations and partnerships constitute an increasingly popular phenomenon (Googins and Rochlin, 2000) in the guise of cross-sector projects that 
are set up explicitly to address social issues and causes that actively engage the partners on an ongoing, continuous basis (Selsky and Parker, 2005). Through such collaborations or partnerships, private corporations and public institutions can help address challenges such as education, health care, poverty, economic development, community capacity building, environmental sustainability, and public safety. The private corporations typically contribute resources - such as time and effort-and move beyond strictly monetary contributions (Waddock, 1988). Through these more or less formalized collaborations or partnerships, private corporations thus transfer, acquire, and share expertise and access to needed resources (Barringer and Harrison, 2000).

Transactional projects of this nature, characterized as constrained, short-term, and largely self-interest-oriented, differ from integrative or developmental projects, which are openended, longer term, and largely common-interest-oriented (Selsky and Parker, 2005). However, in both types of projects, the exchange of value for mutual benefit represents the essence of the partnership (Tennyson, 2003). The selected issues typically are, or appear to be, strategic for the corporate partner-that is, they support the core mission of the corporation (Elbers 2004, cited in Selsky and Parker, 2005) - and potentially enable that organization to earn social respect or trust (Millar, Choi, and Chen, 2004). The nonprofit partner acknowledges that it can achieve less alone than it might have by collaborating. Therefore, in addition to material resources, the nonprofit partner gains key learning possibilities from such partnerships (London, Rondinelli, and O’Neill, 2005).

Examples of these cross-sector, socially oriented collaborations have appeared recently in the disaster relief sector as well (Shister, 2004; Simpson, 2005; Spring, 2006), consisting generally of four types of private corporation-disaster relief agency partnerships (Thomas and 
Fritz, 2006): single organization philanthropic partnerships (e.g., Abbott Laboratories and American Red Cross), multiple organization philanthropic partnerships (e.g., Disaster Relief Network), single-organization integrative partnerships (e.g., TNT and the World Food Program; DHL, the United Nations Development Program, and Office for the Coordination of Humanitarian Affairs), and multiple organization integrative partnerships (e.g., partnership for Quality Medical Donations). This typology largely fits Selsky and Parker's (2005) categorization, such that philanthropic partnerships — which focus on providing goods and services, as well as infrastructure, often on a short-term basis-mirror more transactional projects. Even if some collaborative schemes exist before help is needed or last for a longer period (e.g., South Asia Earthquake Fund, under the leadership of five corporate CEOs), they address the immediate concerns of a crisis. In contrast, single and multiple organization integrative partnerships focus on the longer-term impacts of disaster relief operations; they thus correspond to open-ended integrative or developmental cross-sector, socially oriented partnerships. Corporations and disaster relief agencies make the most of each others' core competencies so that they can deliver assistance more effectively (Thomas and Fritz, 2006) by engaging in initiatives that systematically improve practices in the relief sector. Such initiatives demonstrate the value of support from corporations.

In the following we consider, first, the role of SCM in disaster relief; second, distinctive elements and current SCM practices in this context; and, third, challenges in SCM.

\section{SCM IN DISASTER RELIEF OPERATIONS}

\section{The Role of SCM}


A disaster response involves trade-offs of speed, cost, and accuracy with regard to the type of goods, and their quantities, that are delivered (Davidson, 2006). Therefore, efficient relief supply chains are critical, and SCM and logistics serve as a link between disaster preparedness and response, between procurement and distribution, and between headquarters and the field (Thomas, 2004). In addition, most disaster relief monies get allocated to supply chain and logistics operations, which means these operations largely can determine whether a disaster relief is successful (Van Wassenhove, 2006).

The lifecycle of a disaster relief operation, according to modern conceptualizations, proceeds through a brief needs assessment period, which provides the foundation for developing the disaster relief supply chain (Beamon, 2004). After the supply chain has been established, supplies move to the region affected by the disaster (Long and Wood, 1995). If operations must be sustained for a longer period of time, the supply chain progressively changes and becomes more structured; supplies are provided on a fixed schedule or by request. Finally, disaster relief operations should be reduced, such that the organizations either terminate the supply chain or transfer its operations to local agencies.

One of the complex challenges for these disaster relief agencies pertains to the network of various agencies that exists only because of the disaster (Beamon and Kotleba, 2006; Cassidy, 2003). An agency may have single transactions with some new entities (e.g., the party receiving relief) but repeat transactions with others (e.g., logistics providers). The customers in disaster relief supply chains include not only end-consumers - that is, the victims and survivors of a disaster - but also the various organizations within the supply chain that require emergency services and assistance for the affected population (Gattorna, 2006), which might include donors (i.e., country-specific or donations from outsiders and the private sector), 
governments (i.e., host and neighboring countries), the local community, NGOs, the military, and logistics providers (Kovács and Spens, 2007). Finally, in this supply chain, both regional and extra-regional actors appear, which increases the number of agencies even more.

Yet the challenges are not limited to traditional supply chain issues. Demand for relief is mostly unpredictable, local infrastructure often is destabilized, multiple agencies are involved, transport capacity is often limited, political complexities are intense, and information is fragmented and hard to interpret (Kelly, 1995; Kovács and Spens, 2007; OECD, 2004; Ratliff, 2007). Moreover, overviews of the needs and available resources are difficult to produce (Ergun, Keskinocak and Swann, 2007). As a result, each unique disaster requires a unique solution; no single, standard type of disaster relief supply chain applies to every incident. Many supply chains exist for short times, making them not only unpredictable, but also turbulent and requiring flexibility (Oloruntoba and Gray, 2006). The sudden onset of a disaster also requires a flexible supply chain whose design might need to evolve from an initial emergency response to an ongoing reconstruction operation (Gattorna, 2006). During the emergency response, a supply chain could require an entirely new design from scratch that features rapid response capabilities and suppliers that can deliver a supplier-led solution that involves both innovation and creativity (Gattorna, 2006). Risk taking is encouraged, and mistakes are rarely punished, because the priorities are rapid access to the disaster area and minimizing suffering. Because of increasing demands to demonstrate accountability and transparency though, relief agencies must control their financial expenditures carefully. Furthermore, during ongoing reconstruction operations, the agency generally institutes a more scheduled program and supply chains that reflect more traditional buying behavior in the local community. 
Even with these challenges and knowledge though, relief agencies lack "a general $[\ldots]$ understanding of what good logistics does and can offer: improved efficiency, contingency plans, accountability and reduced cost" (Rickard, 2003: 18). The unpredictability of disasters and the nature of relief funding lead to operations where employee turnover rates are high, technology is fragmented, manual processes are poorly defined, and institutional learning over time is lacking (Thomas and Kopczak, 2005, 2007). Relief supply chains offer much room for improvement (Thomas and Kopczak, 2005, 2007), especially those operated by smaller agencies. We argue that more developed SCM capabilities of private organizations could help enhance the effectiveness and efficiency of relief supply chains (Trunick, 2005; Van Wassenhove, 2006).

\section{Distinctive Elements and Current SCM Practices}

Several key similarities mark commercial and disaster relief SCM, such as the basic principles associated with managing the flows of goods, information, and finances. The main SCM processes also remain the same: demand management, supply management, and fulfillment management (Ernst, 2003). Yet in disaster relief operations, SCM exhibits unique characteristics related to the particular nature of disasters and the technical requirements of disaster relief operations. Other specific characteristics result from the cultural and organizational context of the actors and the site. In Table 1, we summarize some distinctive elements and current practices of SCM in disaster relief operations.

Insert Table 1 about here

Although not comprehensive, this summary provides a wide-ranging overview, according to the two cycles previously discussed. In turn, this overview constitutes an appropriate basis for 
examining the challenges involved in relief agencies' attempts to develop more efficient and effective SCM practices.

\section{Challenges in SCM}

In recent years, the planning and performance of disaster relief operations has improved (McEntire, 1997), as have information systems and coordination among agencies (Whybark, 2007). In this context, the impact of disasters has been reduced by better communication, early warning systems, evacuation procedures, building codes, improved fire fighting and rescue equipment (Whybark, 2007). However, because of their distinctive challenges, as well as the organizational and cultural characteristics of the relief agencies and the disaster area, relief agencies continue to struggle with their operational efficiency, including SCM. To some extent, we can elucidate this issue by comparing the concerns facing disaster relief supply chain and logistics operations with those that corporations faced 15-20 years ago (Rickard, 2003). Primarily, such a comparison suggests the potential for improvement, though the learning curve remains significant.

Three interrelated sets of issues relate to the effort to develop relief agencies' SCM operations into efficient and effective methods: learning, strategizing, and coordinating and measuring issues. These three dimensions connect directly to the specific nature and characteristics of disaster relief agencies and their operations, as we summarize in Table 2. As Beamon (2004) emphasizes, the unpredictable emergency response stage primarily is characterized by specific operational SCM implications, whereas supply chains tend to take on a more conventional structure during the restoration or reconstruction stage. In the remainder of this article, we focus specifically on the emergency response and strategic preparedness stages. 


\section{Learning issues}

The value-oriented culture and management of most disaster relief agencies, combined with the tacit nature of knowledge in disaster relief agencies, frequently results in insufficient consideration of the strategic importance of the supply chain and logistics functions.

Value-oriented culture. Members of disaster relief agencies often appear resourceful, talented, and hardworking (e.g., Bonney, 2003); however, the many volunteers, often temporary, come from various professional backgrounds, which may involve crisis management and disaster relief operations only indirectly. These volunteers tend to have a common value system that drives them to exert positive influences on people's living conditions. The leaders of such NGOs often are value-led activists, commonly with a learning background in humanitarian fields. However, despite their strong commitment to the cause and function, few volunteers have commercial experience with supply chain and logistics management (Gustavsson, 2003), such that neither the various backgrounds of the volunteers nor the altruistic organizational culture provide a basis for the development of efficient and efficient SCM or process integration. In turn, disaster relief agencies too often waste time and money by relying on poorly documented manual processes and logistics. Even as disaster relief workers become more skilled and prepared than ever before and field logisticians grow more common-except perhaps for humanitarian disasters in conflict zones-few skilled SCM and logistics experts appear on scene (Chaikin, 2003). Thus, disaster relief agencies face the particular challenge of attracting and relying on members with management experience, especially in the field of SCM. 


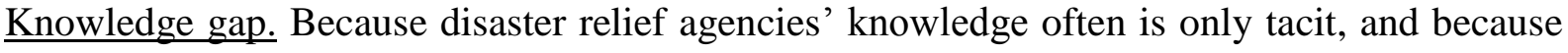
debriefings following a relief operation often are absent or limited in their ability to suggest improvements to relief supply systems, the lessons learned from one disaster event often fade before the next one, and experience does not move easily among disaster events and responders (Samii and Van Wassenhove, 2003). Moreover, the challenges and lack of career advancement for field logisticians result in extreme turnover rates, as high as 80 percent per year (Thomas, 2005). Many field workers partaking in their first relief operation never sign up for a second; one in three field workers quits because of burnout (Gustavsson, 2003). Thus, the expertise of these agencies generally rests within a small group of highly experienced humanitarian field workers, which makes the development of explicit knowledge and expertise, as well as institutional learning, particularly problematic. Disaster relief agencies must find ways to structure their knowledge development processes and systematize the development of SCM training and formation programs.

Utilitarian perspective. Because of the preceding elements, much less attention centers on ensuring the efficient delivery of supplies and relief. Disaster relief agencies often ignore SCM and logistics as auxiliary functions; even international agencies that acknowledge SCMrelated issues as key to the efficiency of their operations often fail to prioritize the development of strong supply chain operations or regard SCM and logistics activities as expenses rather than strategic management components (Fenton, 2003). Most organizations further underestimate the potential role of SCM in disaster relief operations and focus on direct relief operations rather than constraint management (Arminas, 2005). Because in such a scenario, organizations rarely can develop and maintain the level of SCM expertise common to corporate organizations, the challenge becomes to establish and reaffirm the case for more efficient SCM practices in disaster relief operations. 


\section{Strategizing issues}

Funding, or lack thereof, often hinders disaster relief agencies from adopting a strategic posture. The short-term nature of their funding, often earmarked for visible field projects, may prompt limited investments in the development and implementation of more sophisticated SCM tools, as well as limited consideration of strategic matters, such as sourcing, purchasing, and inventory pre-positioning.

Funding bias. Donations, which provide the main funding for relief efforts, often increase immediately after a disaster occurs (Ratliff, 2007). However, for the funded relief to be supplied, a financial supply chain must exist, which often creates a problem, because agencies struggle if their money transfer processes are inadequate or they lack formal arrangements with local financial institutions and suppliers (Russel, 2005). Furthermore, much of this financial support is designated for particular disaster relief operations, especially the direct and visible projects on the field. In this context, the irregular funding cycle forces many smaller agencies to live project to project (Gustavsson, 2003). Increasing competition for funds and tightened donor scrutiny can make the reaction and recovery stages seem like picnics compared with strategic planning and prevention operations. Preparedness opportunities typically weaken, and a difficult challenge for agencies consists of leveraging awareness and sensitizing private and institutional donors to the role and importance of preparedness and strategic concerns.

Technological shortage. Action-focused cultures, tacit knowledge, funding issues, and lack of consideration for SCM practices all hinder the development and management of information systems, information technology, and logistic systems. Even though more sophisticated SCM 
tools could result in lowered costs and more efficient operations in the longer term, agencies have limited human and financial resources to invest in such advances (Thomas, 2003b). Most NGOs lack an efficient electronic infrastructure, and access to information remains tricky or even impossible at several points in the supply chain (Lee and Zbinden, 2003). For example, most disaster relief agencies switch from electronic systems to paper early in the handling process (Gustavsson, 2003) and rely on Excel for their tracking, resulting in little visibility into inbound shipments; this shift in turn impedes the undertaking of receiving, clearing customs, shipping to intermediate warehouses, and distribution along the supply chain (Russel, 2005). Moreover, it appears that few field actors endeavor to assess and define specific technological needs and strategic SCM shortages or advocate for the development and implementation of technology solutions (Ratliff, 2007). A related challenge thus requires developing specific, adaptable technology solutions (Thomas and Kopczak, 2005) that will fit the particular and unique needs of the complex supply chain processes involved in disaster relief operations.

Faltering perspective on sourcing, purchasing, and positioning. Fewer investments in technology or improving SCM practices limit disaster relief agencies' ability to make strategic choices about sourcing, purchasing, and inventory pre-positioning. These organizations should focus more on developing local sources of supply and agreeing on specifications; pre-positioning such nonconsumable items frequently proves valuable, and systematically preestablished supply contracts and deals with suppliers could guarantee the supply of goods (Arminas, 2005; Chaikin, 2003). Although some prominent disaster relief agencies have made significant progress on such issues, other groups consider them distant goals or topics for future reflection, so that the status quo remains and stagnates. Realistic strategic plans remain scarce, and operational inefficiencies persist in the field (Byman et al., 
2000). Developing dedicated, in-depth studies and strategic analyses of SCM components therefore provides a possible challenge for efficient disaster relief in the future.

\section{Coordinating and measuring issues}

Coordination- and measurement-related issues may confuse or complicate task handling at the back end of supply chains. Process coordination during disaster relief operations, as well as among disaster relief actors, often remains limited. Moreover, the regular lack of measurement tools and processes prevents disaster relief agencies from gaining a sound perception of their own operational performance or retaining lessons they may have learned in previous operations.

Coordination struggle. Regular planning in disaster relief supply chains is frequently lacking, suggesting a limited degree of agreement about appropriate processes and their synchronization (Ratliff, 2007). For example, there often is no central database with historical data on transit times, prices paid, or quantities purchased and received (Lee and Zbinden, 2003). Without clear lines of control or communications between the operational and the program side (Fritz Institute, 2004; Gustavsson, 2003), few relief agencies can handle the complex job demanded of the back end of supply chains (Bonney, 2003). Furthermore, coordination difficulties mark the interactions among actors in the field, including the many decentralized agencies and the large numbers of individual volunteers trying to help. The low level of coordination, which results in wasted energy and resources, constitutes a recurrent criticism of disaster relief operations (McEntire, 1999).

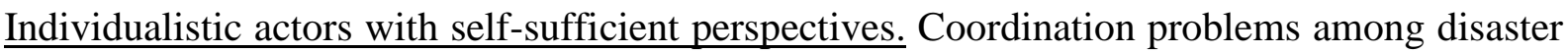
relief agencies result from the complexity associated with cooperating and establishing 
standard processes when these actors may be potential "competitors" (Fritz Institute, 2004). To decrease redundancy, NGOs must work together rather than compete (Beamon and Kotleba, 2006), and collaboration among agencies admittedly has improved in recent years (Samii and Van Wassenhove, 2003) through shared equipment, assets, or resources. However, the lack of communication remains significant, despite the critical need for agencies to share information about their available capabilities before a disaster and the great relevance of interorganizational collaboration for information systems (e.g., Arminas, 2005; Long, 1997). Cooperation should be encouraged in various strategic areas and for longer-term considerations (Chaikin, 2003); similarly, strategic collaborations with, for example, governments, the military, and corporations may offer increasingly important tools for disaster relief agencies (Van Wassenhove, 2006), though they remain rare in practice as a result of cross-sector cultural differences and reciprocal skepticism regarding motivations or competencies. Consequently, developing general emergency logistics standards, as well as effective processes for cooperation and dialogue within the competitive relief environment and with external actors, constitute an ongoing and critical challenge.

Crucial objectives with no goals. Finally, the quality of the relief provided suffers when relief agencies lack a clear overview of their own performance, because this sector rarely measures SCM performance. Reporting becomes more difficult as a result of the lack of information and communication technology, as well as the limited training of field workers (Thomas, 2005). Modest performance measurement efforts mostly focus on reporting the extent of relief, use of monies, and speed of delivery. Defining operational objectives more clearly and then assessing performance with respect to these objectives would allow disaster relief agencies to learn from each operation and provide better services to their beneficiaries in the future (Davidson, 2006). That is, developing key performance indicators could vastly improve SCM practices and disaster relief operations. 
These three interrelated dimensions thus hinder efficient and effective SCM practices in disaster relief; the specific elements and challenges associated with each illustrate that improving existing practices demands a systemic perspective. An attempt to meet these challenges individually likely will have little effect, whereas a concerted evolution of SCMrelated practices in disaster relief may provide significant benefits. From this perspective, private-sector SCM expertise and resources may contribute to the development of improved SCM practices in the disaster relief sector.

\section{Bridging Corporate and Disaster Relief Sectors through CSR}

Despite the differing natures of disaster relief and traditional commercial operations, both sectors offer valuable lessons for the other, especially when they develop relationships and interactions (Murray, 2005). From a disaster relief agency perspective, collaborations with corporate organizations provide not only material and financial support but also exposure to SCM and technical expertise, innovations, and cost efficiency capabilities. Various management and SCM-related tools and concepts developed and implemented for commercial enterprises may fit the disaster relief sector as well if these tools and concepts are carefully translated and if the complexity of disaster relief operations is taken into consideration (Van Wassenhove, 2006).

Conversely, the agility, flexibility, and rapid response capabilities of disaster relief supply chains should offer key lessons for corporations that increasingly need such skills. In specific industries such as delivery companies, as well as for corporations operating in uncertain or unstable regions, more efficient relief efforts can enhance long-term business interests, because strong efforts improve the efficiency of transit hubs in disaster areas and increase the speed of recovery (Simpson, 2005). Disasters negatively affect productivity, growth, and 
macro economic performance throughout the affected society (Ibarrarán et al., 2007), so contributing to disaster preparedness efforts and constructively helping minimize the impact of a disaster could constitute a reason for corporations to partake in such activities. Additional business-related reasons to develop relevant collaborations with disaster relief agencies include improving the organization's reputation among stakeholders, enhancing its license to operate, developing local markets, improving its risk management, and attracting, motivating, and retaining certain categories of employees (Murray and Vogel, 1997; Powell-Smith, 2005; Rochlin and Christoffer, 2000; Turban and Greening, 1997). The modern era largely suggests that a socially responsible attitude represents a necessary condition for business success (Altman, 1998); in such an environment, dedicating corporate resources, efforts, and expertise to socially responsible programs, especially those that mirror core business capabilities, should contribute positively to corporate goodwill (McElhaney, 2007; Porter and Kramer, 1999). In this sense, relationships and interactions between corporations and disaster relief agencies can provide the foundation for potential win-win situations.

The proposed model thus provides a clearer understanding of the potential contributions of corporations to SCM practices in disaster relief operations. Cross-sector, socially oriented collaborations offer key sources of learning and development for disaster relief supply chains (cf. Thomas and Fritz, 2006). In particular, collaborative efforts can foster better, more adequate, and innovative solutions to the challenges faced by most disaster relief agencies. In this sense, we consider three strategic angles inherent in cross-sector collaborations in disaster relief operations: a financial perspective, a capability perspective, and an entanglement perspective. These three distinct perspectives relate to the nature of the discretionary business practices and corporate resource contributions designated for improving community wellbeing by establishing constructive, collaborative processes and helping develop efficient SCM 
practices in disaster relief operations. Combined with the three major dimensions that hinder the adoption and implementation of more efficient SCM practices, these perspectives suggest various options for developing relevant actions and programs that will improve SCM practices from a CSR point of view. Table 3 summarizes these elements and highlights several examples of existing initiatives that bring together corporate and disaster relief actors to improve critical SCM issues.

Insert Table 3 about here

\section{Financial perspective}

Logistics expenses often constitute up to 30 percent of relief agency spending (Spring, 2006). During disasters, many corporations offer cash donations and supply essential goods and services for people in need, yet because of poor communications about needs and availability, many organizations donate unneeded goods that clog runways and storage space (Holland, 2007). Due to the nature and characteristics of disaster relief operations and agencies, we suggest the problem of finding resources to respond in the aftermath of a disaster may be less challenging than finding resources that make the organizations ready to respond (Van Wassenhove, 2006). As Jorge Olague, donor relations officer at the U.N. World Food Programme, notes, “if stocks aren't pre-positioned and staff isn't pre-trained, then it's often too late. Any dollar given before an emergency goes much further than more dollars given after" (quoted in Rowling, 2007). Corporate funding therefore could make an even more significant impact if it were dedicated early enough to disaster relief agencies and enabled them to address key issues such as SCM-related learning, strategizing, and coordinating. Foundations and corporate cash donations also have several advantages over government and individual donations (Ibarrarán et al., 2007), including decreased bureaucracy and fewer reporting 
requirements, greater access to decision makers, quicker fund availability, and longer-term funding. Corporate donors and foundations may have a clearer understanding, compared with individual donors, of the need to finance indirect costs such as recruitment, training, and monitoring (Ibarrarán et al., 2007). Whether through a long- or short-term commitment, efficient financial support from the corporate world can significantly improve SCM practices in disaster relief operations. Organizations such as Vodafone, Citigroup, AIG, and Accenture dedicate significant financial resources to disaster relief agencies to enhance their critical SCM-related and logistics challenges. They also fund innovative training and technology improvements to strengthen the preparedness and coordination abilities of these agencies. That is, it appears that a growing number of organizations increasingly are aware of the complexity of disaster relief efforts and therefore are thinking about how best to provide support (Holland, 2007). Clever financial collaborations represent one way to contribute constructively to the improvement of SCM practices in disaster relief operations.

\section{Capability perspective}

Effective disaster relief operations should be backed up by effective operational processes, appropriate uses of enabling technologies, well-trained logistics personnel, objective performance metrics, and institutionalized learning (Fritz Institute, 2007). By collaborating with leading nonprofit organizations, NGOs, and international relief agencies, private organizations can recommend new ways to use SCM, business, and technology skills. Partnerships therefore might imply a relationship in which both parties not only contribute skills, resources, and expertise but also share risks (Cowe, 2004). These medium- or longerterm partnerships ideally help private corporations achieve something they otherwise could not, such as a strong CSR reputation; the partnering disaster relief agencies also obtain business practice, not just project funding. In this sense, disaster relief agencies should begin 
to think more strategically about how to engage with private corporations to leverage their capabilities and know-how. Corporations such as Intel, UPS, and Vodafone, for example, have established structured, medium-term collaborations with disaster relief agencies such as the International Rescue Committee and the World Food Program, in which they bring their corporate expertise to bear on disaster relief efforts and innovative solutions. Their existing initiatives already have enhanced learning, strategizing, and measuring capabilities on the disaster relief side; they also have contributed to make procurement more efficient and enhanced the effectiveness of information, coordination, and communication systems. Such partnerships offer access to corporate infrastructures and codeveloped processes that help reduce response times and procurement costs substantially, because they entail agreements with disaster relief agencies' suppliers, standard catalogues that facilitate accurate communications of orders from the field, and standardized measurements that recognize the reliability, efficiency, and value of SCM practices. From a capability perspective, these partnerships build on corporations' core competencies to increase the performance and innovation associated with delivering necessary assistance.

\section{Entanglement perspective}

Finally, corporations may commit their SCM knowledge, skills, and resources with a longterm point of view; therefore, they engage comprehensively and persistently with the disaster relief sector. Major logistics giants such as TNT and DHL, for example, provide comprehensive disaster management responses.

In particular, the five-year partnership program between TNT and the World Food Program (WFP) has generated knowledge transfers, hands-on support, and funding and awareness initiatives. With respect to SCM issues, the dedicated resources include cash donations, in- 
kind services, and knowledge transfers. Thus, the WFP gains a novel perspective on its SCM operations; TNT makes consistent investments in training and IT to enhance the WFP's supply chain capabilities and improve its fleet management systems. Furthermore, the partnership relies on organization-wide employee involvement; in 2006, 57 percent of TNT's 128,000 employees participated in the partnership in some form (Bakker, 2006).

Similarly, DHL uses its range of competences, skills, and knowledge to provide constructive help to disaster relief agencies and communities. During disaster prevention and planning cycles, DHL works with the U.N. Development Programme as a strategic partner, focusing on helping national governments and other disaster relief agencies improve their disaster preparedness skills and reducing the potential risk of major disasters. Emergency logistics preparedness planning constitutes a key concentration of DHL's actions. During the reaction and recovery cycle, DHL's most noticeable contributions are the DHL Disaster Response Teams, which consist of specifically trained DHL volunteers who operate in partnership with the U.N. Office for the Coordination of Humanitarian Affairs and national Red Cross and Red Crescent societies.

For both TNT and DHL, involvement in disaster relief operations represents a cornerstone of their CSR strategy and commitment to the community on a global scale. By partnering with major relief actors on a long-term basis by dedicating various corporate resources and sharing core competencies, these corporations demonstrate their powerful engagement in working to improve community well-being. According to the entanglement perspective, these partners reach new levels of integration in their missions, organizations, and activities and thereby progressively enter into a "mutual mission relationship" (Austin, 2000). 
Our three-angle model illustrates how such cross-sector collaborations can enhance SCM practices in the disaster relief sector. Partnerships with corporate actors can benefit disaster relief agencies by improving cost effectiveness, developing innovations, and enhancing capacities. The examples provided herein also illustrate that strong business commitment and leadership to develop disaster relief SCM-related capacities logically should come from business sectors most closely linked to SCM, logistics, and IT issues. Remarkable existing collaborations already involve global corporations and supranational institutions, such as Oxfam or Worldvision. However, smaller disaster relief agencies-which suffer the most significant shortages in their SCM-related practices - seemingly experience more difficulties in developing beneficial partnerships. To improve the response capabilities of a wider range of disaster relief agencies, some multicompany partnerships, such as Disaster Resource Network and Corporations for Humanity, have emerged (Thomas and Fritz, 2006) in an attempt to combine collective corporate resources and best practices and thereby offer a wider array of solutions and expertise to the disaster relief sector. The wide range of cross-sector partnerships reflects this trend, including partnerships that bring together businesses with NGOs and perhaps government agencies (Cowe, 2004).

\section{DISCUSSION AND CONCLUSION}

Cross-sector collaborations among nonprofits, corporations, and governments likely will intensify (Austin, 2000) as a result of nonprofit organizations' search for new resources and more effective organizational approaches, as well as corporate organizations' pursuit of legitimacy and social responsibility. Research therefore must continue to determine how these different sectors can best work together. Moved by extensive media coverage of human 
suffering linked to natural and human-made disasters, as well as increased disaster aid requests, corporations have steadily become more active in the disaster relief field.

This study provides specific insights into how corporations might help improve the SCM practices currently carried out by disaster relief agencies. Despite recognizing them as decisive functions for achieving effective relief operations, many relief actors still ignore logistics and SCM as key strategic functions (Thomas, 2003a). Disaster relief agencies continue to function without SCM professional expertise, tools, and staff. As a result, vast room for improvement exists when it comes to SCM practices in the relief sector.

We approach disaster relief operations with a dual-cycle model that focuses on the key missions of disaster relief agencies: a prevention and planning cycle and a response and recovery cycle. On this conceptual basis, we offer three major contributions that deepen understanding of how business might contribute to improve the SCM practices of disaster relief agencies. First, we provide a concise representation of the current practices and particularities of disaster relief supply chains compared with those in a commercial context. Second, we highlight the main challenges and barriers to the development of more efficient SCM practices in the disaster relief sector, classifying them into three sets of issues: learning, strategizing, and coordinating and measuring. Third, we establish a simple, functional model for understanding how support from corporations and collaborations between corporate actors and disaster relief agencies might help relief agencies meet SCM challenges; this model consists of three strategic perspectives on cross-sector collaborations: financial, capability, and entanglement perspectives. Together, these elements suggest options for collaborative actions and programs that might improve SCM practices from a CSR point of view. 
However, our research is not exempt from limitations. In particular, disaster relief agencies still widely view corporations with suspicion because they fear the reputational risks associated with engaging in corporate partnerships. At the same time, corporations generally do not hold disaster relief agencies and their professionalism and capabilities in high esteem (Thomas and Fritz, 2006). Our research does not address culture clash-related considerations that may play a significant role in the development process of cross-sector, socially oriented partnerships in the disaster relief field. Building constructive corporate-relief agency partnerships to share competencies and foster the spread of technology and ideas often constitutes a difficult task, so the question may become less about whether cross-sector partnerships are right but rather who the right partner is (Powell-Smith, 2005). Further research should help determine common grounds for developing partnerships that build on trust and collaboration.

The variety and complexity of organizational actors and phenomena in disaster relief operations ensures that overriding statements and models cannot represent the entire scope of real-life situations and practices. We do not pretend to make this claim. Rather, we undertake to offer a constructive, resourceful analysis of a contemporary organizational phenomenon and rely on key assumptions to help conceptualize collaborative paths in the disaster relief sector that may improve SCM practices and the effectiveness of relief operations.

\section{REFERENCES}

Altman, B. (1998), “Transformed corporate community relations: a management tool for achieving corporate citizenship", Business and Society Review, Vol. 102, No. 1, pp. 43-51. 
Anderson, M. (1985), "A reconceptualization of the linkages between disasters and development", Disasters, Vol. 9, No. 1. pp. 46-51.

Arminas, D. (2005). "Supply lessons of tsunami aid”, Supply Management, Vol. 10, No. 2, p. 14.

Austin, J. (2000), The Collaboration Challenge: How Nonprofits and Businesses Succeed through Strategic Alliances, Jossey Bass, San Francisco, CA.

Bakker, P. (2006), Fighting world hunger: TNT's partnership with World Food Programme, http://group.tnt.com/socialresponsibility/strategy/movingtheworld/.

Barringer, B. and Harrison, J. (2000), "Walking a tightrope: creating value through interorganizational relationships”, Journal of Management, Vol. 26, No 3, pp. 367-403.

BBC (2004), "Natural disasters on the rise", BBC News, September 17, http://news.bbc.co.uk/2/hi/3666474.stm.

Beamon, B. (2004), "Humanitarian relief chains: issues and challenges", Proceedings of the 34th International Conference on Computers and Industrial Engineering, November 14-15, San Francisco, CA.

Beamon, B. and Kotleba, S. (2006), "Inventory management support systems for emergency humanitarian relief operations in South Sudan", International Journal of Logistics Management, Vol. 17, No. 2, pp. 187-212.

Bonney, J. (2003), “The ultimate logistics challenge”, The Journal of Commerce, December 8, p. 1

Brammer, S. and Millington, A. (2003), “The effect of stakeholder preferences, organizational structure and industry type on corporate community involvement", Journal of Business Ethics, Vol. 45, No. 3, pp. 213-226. 
Byman, D., Lesser, I., Pirnie, B., Benard, C., and Waxman, M. (2000), Strengthening the Partnership: Improving Military Coordination with Relief Agencies and Allies in Humanitarian Operations, Rand Corporation, Santa Monica, CA.

Campbell, T. (2006), “A human rights approach to developing voluntary codes of conduct for multinational corporations”, Business Ethics Quarterly, Vol. 16, No. 2, pp. 255-269.

Carroll, A. (1979). "A three-dimensional conceptual model of corporate performance", Academy of Management Review, Vol. 4, No.4, pp. 497-505.

Carter, N. (1991), Disaster Management: A Disaster Manager's Handbook, ADB, Manila.

Cassidy, W. (2003), “A logistics lifeline”, Traffic World, October 27, p. 1.

Chaikin, D. (2003), “Towards improved logistics: challenges and questions for logisticians and managers", Forced Migration Review, No. 18, p. 10.

Chomilier, B., Samii, R., and Van Wassenhove, L. (2003), “The central role of supply chain management at IFRC", Forced Migration Review, No. 18, pp. 15-18.

Cowe, R. (2004), “Business/NGO Partnerships: What's the Payback?”, Ethical Corporation Magazine, April, pp. 14-18.

Cuny, F. (1985), "What has to be done to increase the effectiveness of disaster interventions", Disasters, Vol. 9, No. 1, pp. 27-28.

Davidson, A. (2006), Key Performance Indicators in Humanitarian Logistics—Executive Summary, MA thesis, MIT Center for Transportation and Logistics, Cambridge, MA, http://ctl.mit.edu/index.pl?id=6136.

Elbers, W. (2004), Doing Business with Business: Development NGOs Interacting with the Corporate Sector, Centre for International Development Issues, Nijmegen.

Ergun, O., Keskinocak, P., and Swann, J. (2007), "Humanitarian relief logistics”, Operations Research/Management Science Today, December, pp. 28-33. 
Ernst, R. (2003), “The academic side of commercial logistics and the importance of this special issue", Forced Migration Review, No. 18, p. 5.

Fenton, G. (2003), “Coordination in the Great Lakes”, Forced Migration Review, No. 18, pp. 23-24.

Friedman, A. and Miles, S. (2002), "Developing stakeholder theory”, Journal of Management Studies, Vol. 39, No. 1, pp. 1-21.

Fritz Institute (2004), "Proceedings of the humanitarian logistics conference-Africa region 2004”, http://www.fritzinstitute.org/prgSC-HLCaf2004-proceedings.htm.

Fritz Institute (2007), "Partners for effective relief: Background", http://www.fritzinstitute.org/prsrm-Backgrounder.htm.

Garner, A. and Harrison, K. (2006), "Early post-tsunami disaster medical assistance to Banda Aceh: A personal account”, Emergency Medicine Australasia, Vol. 18, No. 1, pp. 93-96.

Garriga, E. and Melé, D. (2004). "Corporate social responsibility theories: mapping the territory", Journal of Business Ethics, Vol. 53, No. 1-2, pp. 51-71.

Gattorna, J. (2006), Living Supply Chains, Prentice Hall, Harlow.

Googins, B. and Rochlin, S. (2000), "Creating the partnership society: understanding the rhetoric and reality of cross-sectoral partnerships", Business and Society Review, Vol. 105, No. $1,127-144$.

Gupta, V. and Chary, K. (2006), “Corporate social responsibility at HP”, case study ECCH ref. 706-026-1, ICFAI Center for Management Research, Hyderabad.

Gupta, V. and Perepu, I. (2008), “DHL's corporate social responsibility initiatives: the disaster management program”, case study ECCH ref. 708-016-1, ICFAI Center for Management Research, Hyderabad.

Gustavsson, L. (2003), "Humanitarian logistics: context and challenges", Forced Migration Review, No. 18, pp. 6-8. 
Haas, J., Kates, R., and Bowden, M. (1977), Reconstruction Following Disaster, MIT Press, Cambridge, MA.

Hogg, S. (1980), "Reconstruction following seismic disaster in Venzone, Friuli”, Disasters, Vol. 4, No. 2, pp. 173-185.

Holland, K. (2007), “A new corporate path to disaster relief”, The New York Times, December 23.

Holme, R. and Watts, P. (2000), Corporate Social Responsibility: Making Good Business Sense, World Business Council for Sustainable Development, Conches-Geneva.

Ibarrarán, M., Ruth, M., Ahmad, S., and London, M. (2007). "Climate change and natural disasters: macroeconomic performance and distributional impacts", Environment, Development and Sustainability, in press.

Joyner, B. and Payne, D. (2002), "Evolution and implementation: a study of values, business ethics and corporate social responsibility", Journal of Business Ethics, Vol. 41, No. 4, pp. 297-311.

Kelly, C. (1995), “A framework for improving operational effectiveness and cost efficiency in emergency planning and response", Disaster Prevention and Management, Vol. 4, No. 3, pp. 25-31.

Kelly, C. (1998), "Simplifying disasters: developing a model for complex non-linear events", Australian Journal of Emergency Management, Vol. 14, No. 1, pp. 25-27.

Kolk, A. and van Tulder, R. (2002), “The effectiveness of self-regulation: corporate codes of conduct and child labour”, European Management Journal, Vol. 20, No. 3, pp. 260-271.

Kolmannskog, V. (2008), Future Flood of Refugees: A Comment on Climate Change, Conflict and Forced Migration, Norwegian Refugee Council, Oslo.

Kotler, P. and Lee, N. (2005), Corporate Social Responsibility: Doing the Most Good for Your Company and Your Cause, Wiley, Hoboken, NJ. 
Kovács, G. and Spens, K.M. (2007), "Humanitarian logistics in disaster relief operations", International Journal of Physical Distribution \& Logistics Management, Vol. 37, No. 2, pp. 99-114.

Lee, H. and Zbinden, M. (2003), "Marrying logistics and technology for effective relief", Forced Migration Review, No. 18, pp. 34-35.

Lichtenstein, D.R., Drumwright, M.E., and Braig, B.M. (2004), "The effect of corporate social responsibility on customer donations to corporate-supported nonprofits", Journal of Marketing, Vol. 68, No. 4, pp. 16-32.

Lindgreen, A., Swaen, V., and Johnston, W.J. (2008), “Corporate social responsibility: an empirical investigation of U.S. organizations", Journal of Business Ethics, in press.

London, T., Rondinelli, D., and O’Neill, H. (2005), “Strange bedfellows: alliances between corporations and nonprofits". In Shenkar, O. and Reuer, J. (Eds.), Handbook of Strategic Alliances, Sage, Thousand Oaks, CA, pp. 353-366.

Long, D. (1997), “Logistics for disaster relief: Engineering on the run”, IIE Solutions, Vol. 29, No. 6, pp. 26-29.

Long, D. and Wood, D. (1995), "The logistics of famine relief", Journal of Business Logistics, Vol. 16, No. 1, pp. 213-229.

Ludema, M. and Roos, H. (2000), "Military and civil logistic support of humanitarian relief operations", Proceedings of the 10th International Council on Systems Engineering Annual International Symposium, July 16-20, Minneapolis, MN.

Luo, X. and Bhattacharya, C.B. (2006), “Corporate social responsibility, customer satisfaction and market value", Journal of Marketing, Vol. 70, No. 4, pp. 1-18.

Maignan, I., Ferrell, O.C., and Hult, T. (1999), “Corporate citizenship: cultural antecedents and business benefits", Journal of the Academy of Marketing Science, Vol. 27, No. 4, pp. 455-469. 
Maon, F., Lindgreen, A., and Swaen, V. (2008), "Designing and implementing corporate social responsibility: an integrative framework grounded in theory and practice", Journal of Business Ethics, in press.

McElhaney, K. (2007), A Catechism on CSR, Ernst \& Young Entrepreneur of the Year Program, http://www.haas.berkeley.edu/responsiblebusiness/CSR\%20Catechism.pdf.

McEntire, D. (1999), "Issues in disaster relief: progress, perpetual problems and prospective solutions", Disaster Prevention and Management, Vol. 8 No.5, pp. 351-61.

Millar, C., Choi, C., and Chen, S. (2004), “Global strategic partnerships between MNEs and NGOs: drivers of change and ethical issues", Business and Society Review, Vol. 109, No. 4, pp. 395-414.

Murray, K., and Vogel, C. (1997), "Using a hierarchy-of-effects approach to gauge the effectiveness of corporate social responsibility to generate goodwill toward the firm: financial versus non-financial impacts", Journal of Business Research, Vol. 38, No. 2, pp. 141-159.

Murray, S. (2005), "How to deliver on the promises: supply chain logistics—humanitarian agencies are learning lessons from business in bringing essential supplies to regions hit by the tsunami”, Financial Times, January 7, p. 9.

National Governors Association (1979), Emergency Preparedness Project, DCPA, Washington, D.C.

Neal, D. (1997), "Reconsidering the phases of disaster", International Journal of Mass Emergencies and Disasters, Vol. 15, No. 2, pp. 239-264.

Nijhof, A., de Bruijn, T., and Honders, H. (2008), "Partnerships for corporate social responsibility: a review of concepts and strategic options", Management Decision, Vol. 46, No. 1, pp. 152-167.

OECD (2004), Large-scale Disasters: Lessons Learned, OECD Publications, Paris. 
Oliver-Smith, A. (2006), Disasters and forced migration in the 21 st century, http://understandingkatrina.ssrc.org/Oliver-Smith (accessed 20 November 2007).

Oloruntoba, R. and Gray, R. (2006), “Humanitarian aid: an agile supply chain?” Supply Chain Management, Vol. 11, No. 2. pp. 115-120.

Oxfam (2007), "Climate alarm: disasters increase as climate change bites", Oxfam Briefing Paper, No. 108.

Porter, M., and Kramer, M. (1999), "Philanthropy's new agenda: creating value”, Harvard Business Review, Vol. 77, No. 6, pp. 121-130.

Powell-Smith, A. (2005), "Finding the right corporate NGO partnership", Corporate Responsibility Management, Vol. 2, No. 1, pp. 14-15.

Rajshekar, N. and Iyengar, H. (2004), "Shell's global social responsibility initiatives", case study ECCH ref. 704-020-1, ICFAI Business School Case Development Centre, Hyderabad.

Ratliff, D. (2007), "The challenge of humanitarian logistics", Operations Research/Management Science Today, December, p. 31.

Rickard, J. (2003), “A logistician's plea”, Forced Migration Review, No. 18, p. 9.

Rochlin, S. and Christoffer, B. (2000), Making the Business Case: Determining the Value of Corporate Community Involvement, Research paper series, Boston College Center for Corporate Citizenship, Boston, MA.

Rowling, M. (2007), Big business goes humanitarian, http://www.alertnet.org/db/blogs/20316/2007/02/28-104607-1.htm.

Russel, T. (2005). The Humanitarian Relief Supply Chain: Analysis of the 2004 South East Asia Earthquake and Tsunami, MA thesis, MIT Center for Transportation and Logistics, Cambridge, MA, http://ctl.mit.edu/metadot/index.pl?id=6156. 
Safran, P. (2003), “A strategic approach for disaster and emergency assistance”, Proceedings of the 5th Asian Disaster Reduction Center International Meeting and the 2nd UN-ISDR Asian Meeting, January 15-17, Kobe.

Samii, R. and Van Wassenhove, L. (2003), The United Nations Joint Logistics Centre (UNJLC): The Genesis of a Humanitarian Relief Coordination Platform, case study 02/2003-5093, INSEAD, Fontainebleau.

Samii, R. and Van Wassehove, L. (2004), The TPG-WFP Partnership: Learning how to Dance, case study 04/2004-5194, INSEAD, Fontainebleau.

Selsky, J. and Parker, B. (2005), "Cross-sector partnerships to address social issues: challenges to theory and practice”, Journal of Management, Vol. 31, No. 6, pp. 849-873.

Shaluf, I. (2008), “Technological disaster stages and management”, Disaster Prevention and Management, Vol. 17, No. 1, pp. 114-126.

Shister, N. (2004), "Bringing best practices to emergency food logistics", World Trade, Vol. 17, No. 2, pp. 36-38.

Simpson, G. (2005), "Just in time: in year of disasters, experts bring order to chaos of relief", The Wall Street Journal, November 22, p. A.1.

Spring, S. (2006), "Relief when you need it: can FedEx, DHL and TNT bring the delivery of emergency aid into the 21 st century?", Newsweek, September 11.

Tatham, P. and Kovacs, G. (2007), "An initial investigation into the application of the military sea-basing concept to the provision of immediate relief in a rapid onset disaster", Proceedings of the Productions and Operations Management Systems 18th Annual Conference, May 4-7, Dallas, TX.

Tennyson, R. (2003), The Partnering Toolbook, The International Business Leaders Forum and the Global Alliance for Improved Nutrition, London.

Thomas, A. (2003a), "Why logistics”, Forced Migration Review, No. 18, p. 18. 
Thomas, A. (2003b), Humanitarian Logistics: Enabling Disaster Response, White paper, Fritz Institute, San Francisco, CA.

Thomas, A. (2004), "Leveraging private expertise for humanitarian supply chains", Forced Migration Review, No. 21, pp. 64-65.

Thomas, A. (2005), "Humanitarian logistics: matching recognition with responsibility", AsiaPacific Development Review, June, pp. 32-34.

Thomas, A. and Fritz, L. (2006), "Disaster relief, Inc.”, Harvard Business Review, Vol. 84, No 11, pp. 114-126.

Thomas, A. and Kopczak, L. (2005), From Logistics to Supply Chain Management: The Path forward in the Humanitarian Sector, White paper, Fritz Institute, San Francisco, CA.

Thomas, A. and Kopczak, L. (2007), "Life-saving supply chains and the path forward". In Lee, H. and Lee, C.-Y. (Eds.), Building Supply Chain Excellence in Emerging Economies, Springer Science and Business Media LLC, London, pp. 93-111.

Trunick, P. (2005), “Logistics when it counts”, Logistics Today, Vol. 46, No. 2, p. 38

Turban, D. and Greening, D. (1997), "Corporate social performance and organizational attractiveness to prospective employees", Academy of Management Journal, Vol. 40, No. 3, pp. 658-672.

United Nations (1992), Glossary: Internationally Agreed Glossary of Basic Terms Related to Disaster Management, UN International Decade for Natural Disaster Reduction, Geneva.

United Nations, (2007), Disaster Risk Reduction: 2007 Global Review, UN International Strategy for Disaster Reduction, Geneva.

University of Arkansas (2005), Hurricane Katrina Showed Critical Importance of Logistics and Supply-Chain Management, http://dailyheadlines.uark.edu/5471.htm.

Van Wassenhove, L. (2006), "Humanitarian aid logistics: supply chain management in high gear", Journal of the Operational Research Society, Vol. 57, No. 5, pp. 475-489. 
Vogel, D. (1978), Lobbying the Corporation: Citizen Challenges to Business Authority, Basic books, New York, NY.

Vogel, D. (2005), The Market for Virtue. The Potential and Limits of Corporate Social Responsibility, Brookings Institution Press, Washington, D.C.

Waddock, S. (1988), "Building successful partnerships", Sloan Management Review, Vol. 29, No. 4, pp. 17-23.

Whybark, D. (2007), "Issues in managing disaster relief inventories", International Journal of Production Economics, Vol. 108, No. 1-2, pp. 228-235.

Wills, J. (2002), "Bargaining for the space to organize in the global economy: a review of the Accor-IUF trade union rights agreement", Review of International Political Economy, Vol. 9, No. 4, pp. 675-700.

World Bank. (2001), Attacking Poverty, Development report 2000/2001, World Bank, Washington, D.C. 
Figure 1. A dual cycle model of disaster relief operations

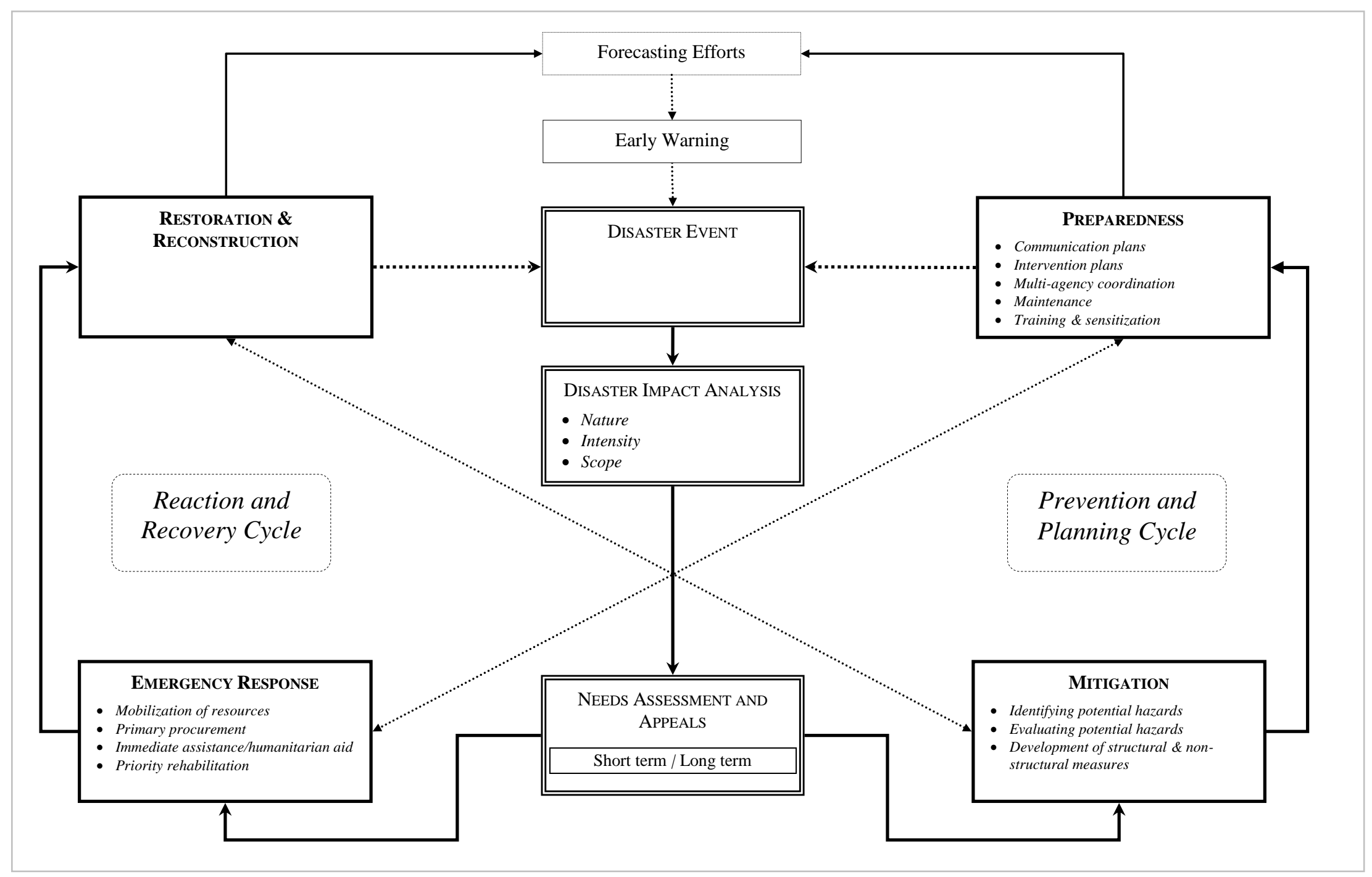


Table 1. Distinctive elements and current practices of SCM in disaster relief operations

\begin{tabular}{|c|c|c|}
\hline & $\begin{array}{l}\text { SCM-RELATED } \\
\text { DIMENSIONS }\end{array}$ & Characteristics of Current Practices in Disaster Relief Operations \\
\hline \multirow{15}{*}{$\begin{array}{l}\text { REACTION } \\
\text { AND } \\
\text { RECOVERY }\end{array}$} & Ultimate goal & $\begin{array}{l}\text { - Limit mortality \& alleviate suffering in emergency response stage } \\
\text { - Efficient technical and material support during the rehabilitation/ reconstruction stage }\end{array}$ \\
\hline & Faced demand & $\begin{array}{l}\text { - Involuntary } \\
\text { - Event-specific } \\
\text { - Need for supplies and people assessed by suppliers } \\
\text { - Unstable demand in emergency response stage, less volatile in rehabilitation/ reconstruction stage }\end{array}$ \\
\hline & Customers & $\begin{array}{l}\text { - Victims, survivors, local communities, local authorities, other disaster relief agencies } \\
\text { - Often characterized by cultural discrepancies }\end{array}$ \\
\hline & $\begin{array}{l}\text { Preliminary needs } \\
\text { assessment }\end{array}$ & $\begin{array}{l}\text { - Mainly through quickly deployed small multidisciplinary teams of experienced humanitarian workers usually } \\
\text { including a logistician. }\end{array}$ \\
\hline & Scope of operations & $\begin{array}{l}\text { - Variable size range and event-specific } \\
\text { - Sometimes geographically moving as disaster situation evolve or survivors and refugees are taken in charge }\end{array}$ \\
\hline & $\begin{array}{l}\text { Distribution strategy } \\
\text { and network }\end{array}$ & $\begin{array}{l}\text { - Local infrastructure (including communication networks) is often largely destabilized or destroyed, } \\
\text { generating potential congestion problems } \\
\text { - Transport capacity is often limited } \\
\text { - Supplies usually shipped to an entry point and then moved to collection sites } \\
\text { - "Last mile" difficulties } \\
\text { - Region is potentially unknown/remote part of the world }\end{array}$ \\
\hline & Lead times & $\begin{array}{l}\text { - Ideally, as short as possible in emergency response stage where demands and needs are concurrent. It } \\
\text { dramatically affects inventory availability and procurement processes } \\
\text { - More conventional time frame in rehabilitation/reconstruction phase }\end{array}$ \\
\hline & Informational basis & - Information often lacking, fragmentary or/and unreliable \\
\hline & Other field actors & - Various. Mostly NGOs, international agencies, army forces and local governments and agencies \\
\hline & $\begin{array}{l}\text { Organizational span } \\
\text { of control }\end{array}$ & $\begin{array}{l}\text { - Limited due to complexities of events, information deficiencies and number and nature of other actors } \\
\text { - Political issues linked to control supplies and population rescued frequently at play }\end{array}$ \\
\hline & $\begin{array}{l}\text { Coordination } \\
\text { structure }\end{array}$ & $\begin{array}{l}\text { - Coordination at local level often limited. Local authorities sometimes inexperienced, lacking resources or } \\
\text { overtaken by events } \\
\text { - On the field collaboration and cooperation has improved but remains reduced. In emergency response stage, } \\
\text { sometimes competition for local resources and infrastructures } \\
\text { - Often, commodities sent in from all over the world without consultation or coordination with teams on the } \\
\text { ground }\end{array}$ \\
\hline & $\begin{array}{l}\text { Supply chain } \\
\text { orientation }\end{array}$ & $\begin{array}{l}\text { - In emergency response phase, supplies are provided without waiting for demand to be accurately determined. } \\
\text { Supplies are "pushed". } \\
\text { - In the rehabilitation/reconstruction stage, need determines the volume of supplies being provided. Supplies } \\
\text { are progressively "pulled". }\end{array}$ \\
\hline & $\begin{array}{l}\text { Purchasing } \\
\text { orientation }\end{array}$ & $\begin{array}{l}\text { - Focus on the purchase items in emergency response phase. Limited importance of cost dimension } \\
\text { - Focus on the purchase items and as well as on cost in rehabilitation/reconstruction stage } \\
\text { - Efforts to source locally in order to lower cost of supplies and shipping and benefit local economy }\end{array}$ \\
\hline & Purchasing operators & - Mainly operational and tactical purchasers \\
\hline & KPIs & - Limited. Mainly time from order to delivery \\
\hline \multirow{6}{*}{$\begin{array}{l}\text { PREVENTION } \\
\text { AND } \\
\text { PLANNING }\end{array}$} & Demand forecast & - Limited due to mostly unpredictable demand and often rudimentary technological tools \\
\hline & $\begin{array}{l}\text { Inventory } \\
\text { management }\end{array}$ & $\begin{array}{l}\text { - Quantity management difficult due to variability of demand, location, lead times, and scope. Standardized } \\
\text { items (e.g. kits) are pre-assembled and stocked by important actors. } \\
\text { - Strategic pre-positioning of stocks difficult due to global range of operations. Possibilities through disasters } \\
\text { occurrence analysis (important actors mainly). }\end{array}$ \\
\hline & Financial flow & $\begin{array}{l}\text { - Funding mostly dependent upon donors } \\
\text { - Numerous time delays due to closeness between demands and operations } \\
\text { - Competition for funding generates focus on donors' expectations and demands for visible impact and actions } \\
\text { linked to their donations. }\end{array}$ \\
\hline & Resources dedication & $\begin{array}{l}\text { - Limited resource dedication to operation preparation and planning, "on the rush" orientation. Can generate } \\
\text { problems with respect to less visible actions and longer term investments } \\
\text { - SCM \& logistics still often considered as a support functions. } \\
\text { - Limited number of expert logisticians }\end{array}$ \\
\hline & $\begin{array}{l}\text { Information } \\
\text { technology } \\
\text { infrastructure }\end{array}$ & $\begin{array}{l}\text { - Limited use of information systems and high-performing supply chain instruments. Work mainly based on } \\
\text { manual processes, trivial software such as Microsoft Excel and key people experience. } \\
\text { - Progressive development and adoption of up-to-date/ specific SCM tools due to recent years } \\
\text { acknowledgement of potential efficiency gains and sensitization by external actors (e.g. Fritz institute) }\end{array}$ \\
\hline & Strategic partnerships & $\begin{array}{l}\text { - Still limited collaboration and coordination between relief actors as well as between relief actors and } \\
\text { suppliers' network } \\
\text { - Important actors often have strategic agreement with international suppliers of standard relief items (e.g. } \\
\text { tents, blankets or survival kits). }\end{array}$ \\
\hline
\end{tabular}


Table 2. Challenges for disaster relief organizations in SCM

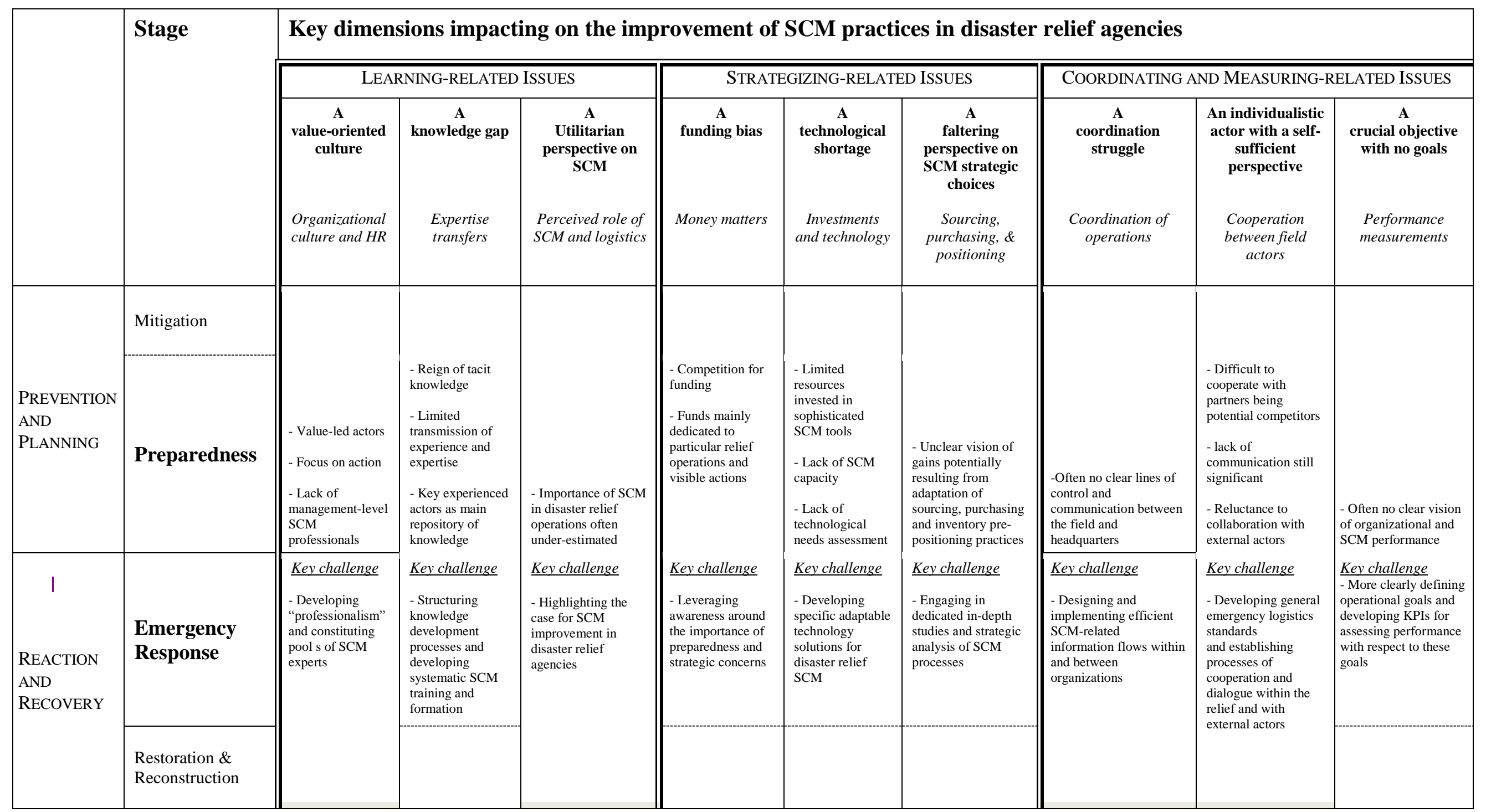


Table 3. Bridging corporate expertise and resources with disaster relief agencies' challenges

\begin{tabular}{|c|c|c|c|}
\hline & \multicolumn{3}{|c|}{ Key dimensions for SCM practices improvement in disaster relief operations } \\
\hline $\begin{array}{l}\text { Potential } \\
\text { collaboration } \\
\text { basis }\end{array}$ & LEARNING & STRATEGIZING & COORDINATING AND MEASURING \\
\hline \multirow{3}{*}{$\begin{array}{l}\text { Financial } \\
\text { perspective }\end{array}$} & \multicolumn{2}{|c|}{$\begin{array}{l}\text { - AIG- International Rescue Committee Sponsorship American International Group, Inc. (AIG) sponsored The International } \\
\text { Rescue Committee to boost the IRC's ability to respond to humanitarian emergencies on short notice. AIG's support will help fund } \\
\text { innovative training and technology to strengthen the preparedness abilities of the IRC's Emergency Response Team. It will also enable } \\
\text { the IRC to establish a logistics and storage base in Dubai, U.A.E. From this strategic location, the IRC will be able to rapidly dispatch } \\
\text { supplies to Africa, Asia, and Europe, enabling teams on the ground to quickly begin services }\end{array}$} & \multirow[b]{2}{*}{$\begin{array}{l}\text { - Oracle/Sun Microsystems/Accenture - Aidmatrix } \\
\text { Sponsorship. Together with other US corporations, these business } \\
\text { actors financially sponsor the Aidmatrix Foundation. The Aidmatrix } \\
\text { Network links nonprofit, government and business sectors to improve } \\
\text { disaster relief. It has developed a set of solutions that improves the flow } \\
\text { of humanitarian aid in times of disaster response and recovery and } \\
\text { automates much of the cumbersome process that is performed manually }\end{array}$} \\
\hline & - & $\begin{array}{l}\text { - Aviva/Vodafone (Group Foundation) - Oxfam } \\
\text { Sponsorship. In 2006, Both corporations were founding } \\
\text { sponsors of the "Oxfam } 365 \text { Programme", an initiative aimed at } \\
\text { funding a global rapid response team of aid workers and } \\
\text { maintaining the UK's biggest warehouse with a stockpile of } \\
\text { emergency supplies. It allows the NGO to think and work more } \\
\text { strategically by improving the timeliness and predictability of } \\
\text { emergency aid. } \\
\text { - Citigroup - World Food Programme Collaboration. In } \\
\text { 2007, Citigroup donated funding to WFP Emergency Network to } \\
\text { boost WFP's ability to assess food shortages in crisis-prone } \\
\text { countries. }\end{array}$ & \\
\hline & \multicolumn{3}{|c|}{$\begin{array}{l}\text { - FedEx-American Red Cross Sponsorship. FedEx has committed significant financial support over the next five years to the American Red Cross, and has provided funding for the International Federation of } \\
\text { Red Cross and Red Crescent Societies in support of the International Federation Global Disaster Management and Coordination Appeal, which is an international disaster preparedness training initiative. FedEx also } \\
\text { created a miniature version of its own Memphis, Tennessee, control room at the American Red Cross headquarters }\end{array}$} \\
\hline \multirow{3}{*}{$\begin{array}{l}\text { Capability } \\
\text { perspective }\end{array}$} & \multirow{2}{*}{$\begin{array}{l}\text { - Booz Allen Hamilton - World Vision (WVI) } \\
\text { Collaboration. To streamline WVI's global supply chain, Booz } \\
\text { Allen Hamilton conducted a pro bono assessment that with } \\
\text { internal and external experts in } 7 \text { countries. Team concluded that } \\
\text { WVI's food distribution supply chain was outstanding, but that } \\
\text { increasingly large and complex non-food related programs would } \\
\text { require continuous enhancement of its capabilities. A comparison } \\
\text { to other relief agencies and best practices from the commercial } \\
\text { sector identified opportunities for improvement in several of } \\
\text { WVI's response and reconstruction capabilities. In partnership } \\
\text { with WVI, the team created a plan for building new capabilities, } \\
\text { which would generate substantial efficiencies that could then be } \\
\text { channeled into more relief assistance. Findings indicated that a } \\
\text { combination of short- and long-term changes could save WVI as } \\
\text { much as } \$ 36 \text { million within } 4 \text { years. }\end{array}$} & $\begin{array}{l}\text { - UPS-UNHRD collaboration. Since 2003, UPS offers free } \\
\text { warehousing facilities to the United Nations Humanitarian } \\
\text { Response Depots (UNHRD), run by the World Food Programme } \\
\text { (WFP) in Panama. It allows stocking vital supplies such as high- } \\
\text { energy biscuits, drugs and other rapid response equipment } \\
\text { essential for disaster relief emergency operations. TNT develops a } \\
\text { similar initiative in Ghana. }\end{array}$ & $\begin{array}{l}\text { - IBM. IBM has helped developing and using open source software (e.g. } \\
\text { Sahana program in Sri Lanka, Indonesia and India to manage logistics } \\
\text { for refugee sites, identify bodies, track displaced persons and coordinate } \\
\text { services. Also, they donated computers for governments, NGOs, } \\
\text { employees and volunteers and trained them to enter data and use the } \\
\text { new open source systems. IBM also has a group of people with specific } \\
\text { technical expertise in relief efforts who are deployed across borders to } \\
\text { disaster areas. }\end{array}$ \\
\hline & & \multicolumn{2}{|c|}{$\begin{array}{l}\text { - Intel/Solectron -International Rescue Committee -collaboration. Facilitated by Fritz Institute, this cross-sector collaboration } \\
\text { brought corporate expertise on the disaster relief side allowed significantly streamlining procurement and creating processes to substantially } \\
\text { reduce response time by reaching agreements with suppliers, developing a standard catalogue to facilitate the accurate communications of } \\
\text { order from the field, and establishing standard measurements for reliability, efficiency and value of suppliers. }\end{array}$} \\
\hline & \multicolumn{3}{|c|}{$\begin{array}{l}\text { - Vodafone (Group Foundation) - World Food Program - United Nations Foundation Collaboration. In 2008, the three organizations sponsored and launched a global partnership for emergency } \\
\text { communication. Aim is to increase the effectiveness of the information and communications technology (ICT) response to major emergencies and disasters. It will be open to the global community of humanitarian } \\
\text { relief agencies. The focus of the partnership will be to standardize ICT solutions used by global aid organizations to improve the speed with which critical communications networks can be established in the } \\
\text { immediate aftermath of a disaster or crisis }\end{array}$} \\
\hline Fntanglement & \multicolumn{3}{|c|}{ - TPG (TNT)-World Food Program collaboration. Since 2002, TNT has been an active partner of the World Food Program through the "Moving the World Program". TNT has committed its knowledge, } \\
\hline
\end{tabular}


skills and resources to support WFP. To date TNT has invested $€ 40$ million in the partnership in the form of hands-on support in emergencies, knowledge transfer projects to help WFP to be more efficient and effective, and advocacy and fundraising activities. Knowledge transfer is considered as the backbone of TNT's partnership with WFP. TNT staff mainly helps developing and implementing WFP programs and
initiatives in 4 distinct SCM-related areas: transport optimization, fleet management, aviation and customs support.

- DHL Disaster Management Program. With a comprehensive logistics network and a worldwide presence DHL considers they are uniquely placed to help people and communities affected by major sudde onset natural disasters. Among the three key components of DHL's disaster management program, two are directly linked top SCM issues: (1) sharing skills and knowledge in disaster preparedness phase, (2) 
